\title{
The diversity of Salmonella serovar isolates originating from Indonesia
}

\author{
R.H.H. Nelwan, Julianti Gunawan'1, Sri Poernomo²
}

\begin{abstract}
Abstrak
Sangat jarang terjadi suatu uji coba klinik demam tifoid dilanjutkan sampai setelah penderita keluar dari rumah sakit dan terus menerus dipantau apakah penderita menjadi karier S. typhi atau S. paratyphi yang sama dengan bakteri serupa yang pernah diisolasi sewaktu mereka dirawat di rumah sakit. Penelitian ini dilaksanakan selama 7 tahun (1990 - 1997). Sepuluh jenis serovar Salmonella telah ditemukan kembali dari feses penderita asimptomatik pasca demam tifoid, meliputi: S. Weltevreden, S. Kentucky, S. Agona, S. Lexington, S. Newport, S. Blockley, S. Sofea, S. Virchow, S. Derby, dan S. Javiana, Sebelum penelitian ini Balai Penelitian Penyakit Hewan pernah menemukan S. Typhimuriurn dan S. Kreveld. Data yang dikemukakan oleh Australian Salmonella Surveillance Report (1992), jenis serovar Salmonella berikut ini dilaporkan berasal dari Indonesia: S. Livingstone, S. Adelaide, S. Berta, S. Hadar, S. Thompson, S. Senftenberg, S. Infantis, S. Braenderup, S. Heidelberg, S. Isangi, S. Potsdam, S. Amsterdam, S. Duesseldorf, S. Emek dan S. Enteritidis. Dilaporkan bahwa S. Livingstone pernah diisolasi pula dari cairan serebrospinal yang jarang memberikan hasil isolasi positif. Dengan demikian jelaslah bagi kita semua untuk mengantisipasi masalah Salmonellosis secara lebih serius di abad mendatang bukan hanya untuk kepentingan masyarakat Indonesia yang mungkin telah berubah daya imunitasnya, namun juga untuk kepentingan orang asing dan pariwisata.
\end{abstract}

\begin{abstract}
A rare opportunity existed when clinical trials for typhoid fever were conducted and patients were followed - tup after discharged from the hospital for a possible post-treatment carriage of Salmonella typhi or paratyphi that was previously isolated during their stay in the hospital. These studies covered in a time span of 7 years (mid - 1990 up to mid 1997). 10 different Salmonella serovars were recovered from the faecal specimens from asymptomatic post-typhoid fever patients that included: S. Weltevreden, S. Kentucky, S. Agona, S. Lexington, S. Newport, S. Blockley, S. Sofea, S. Virchow, S. Derby and S. Javiana. Previously reported species (Research Intitute for Veterinary Science) included: S. typhimurium and S. Kreveld. From the Australian Salmonella Surveillance Report (1992) the following Salmonella serovars were implicated to have been imported from Indonesia: S. Livingstone, S. Adelaide, S. Berta, S. Hadar, S. Thompson, S. Senftenberg, S. Livingstone, S. Infantis, S. Braenderup, S. Heidelberg, S. Isangi, S. Potsdam, S. Amsterdam, S. Duesseldorf, S. Emek and S. Enteritidis. Unusual isolate site included cerebrospinal fluid (S. Livingstone). It is more than clear that we have to be prepared to deal with the problem of Salmonellosis seriously in the next century not only in our local population who may have lost part of their immunity but also to protect our top foreign exchange earning tourist industry.
\end{abstract}

Division of Tropical and Infectious Diseases,

Department of Medicine, Faculty of Medicine,

University of Indonesia, Jakarta, Indonesia.

'Department of Microbiology, Persahabatan Hospital, Jakarta, Indonesia

${ }^{2}$ Research Institute for Veterinary Science, Bogor, Indonesia. 